๑ А. П. Гавриш, д.т.н., професор, Т. А. Роїк, д.т.н., професор, П. О. Киричок, д.т.н., професор, С. М. Зигуля, ст. викладач, Ю. Ю. Віцюк, к.т.н., НТУУ «КПІ», Киї̈, Україна

\title{
ОПТИМІЗАЦІЯ ПРОЦЕСУ ТОНКОГО ШЛІФУВАННЯ ЗНОСОСТІЙКИХ КОМПОЗИТНИХ ДЕТАЛЕЙ ОБЕРТАННЯ ПОЛІГРАФІЧНИХ МАШИН ПО ЧИСЛУ ОПЕРАЦІЙ
}

В статті наведені результати теоретико-експериментальних досліджень 3 оптимізації технологічного процесу тонкого абразивного шліфування високозносостійких деталей тертя поліграфічних машин, які виготовлені з нових типів сплавів, що синтезовані на основі відходів високолегованих штампованих та інструментальних сталей, а також композитних алюмінієвих сплавів, по числу операцій. Розроблена нова методика оцінки продуктивності шліфування з урахуванням вимог високої якості поверхонь деталей та факторів економіки виробництва. Встановлені аналітичні залежності, які поєднують вимоги до абразивних інструментів, режимам різання, параметрам шорсткості поверхонь деталей та питання економіки процесу виробництва, в першу чергу, високої продуктивності процесу шліфування. Розроблені рекомендації для виробництва.

Ключові слова: композитні матеріали; абразивне шліфування; шорсткість поверхні; продуктивність процесу шліфування.

\section{Постановка проблеми}

Однією з центральних проблем розвитку сучасного поліграфічного машинобудування $€$ безперервне підвищення параметрів надійності, зносостійкості, довговічності та ремонтоздатності комплексів друкарської техніки. В останні роки для суттєвого збільшення експлуатаційних властивостей поліграфічних машин і, в першу чергу, деталей пар тертя їх вузлів і механізмів були синтезовані та впроваджені у виробництво створені на основі шламових шліфуваль(C) $2015 \mathrm{p}$. них відходів високолегованих інструментальних сталей 86ХНФТ, 5ХЗВЗМФС, 11РЗАМЗФ, 7ХГ2ВМФ та алюмінієвих сплавів АК12М2МгН, АM4,5Кд, АК8МЗг [1-5]. Вони придатні працювати у жорстких умовах експлуатації (швидкість тертя ковзання близько 1 м/с, температура у зоні контакту може сягати $400-500^{\circ} \mathrm{C}$, питомий тиск у межах 2-8 МПа, агресивне середовище - кисень повітря, виробничий абразивний пил та ін.).

Як відомо[2-4], параметри якості поверхонь деталей тертя 
(параметр шорсткості $\mathrm{R}_{\mathrm{a}}$, ступінь наклепу $\mathrm{K}$, глибина наклепу h, рівень та знак залишкових напружень поверхневого шару оброблення) суттєво впливають на зносостійкість деталей та строк їх служби[1, 4, 6-9].

Створення нових високозносостійких композитних матеріалів супроводжувалось виконанням розгалужених досліджень з вивчення впливу технологічних факторів оброблення (режими різання, склад шліфувального кругу, матеріал зерна інструменту, тип мастильноохолоджуючої рідини та ін.) на якість поверхонь деталей тертя [2-4]. На основі цих досліджень були розроблені типові технологічні процеси, які на сьогодні набули характеру регламентів та стандартів підприємств.

На жаль, поза увагою дослідників залишились питання, що тісно пов'язані з продуктивністю виробництва. Це має не тільки технічне, а і важливе економічне значення, особливо, в умовах безперервно зростаючої на ринках конкуренції виробничників поліграфічної техніки. Тому оптимізація процесу тонкого шліфування зносостійких композитних деталей обертання поліграфічних машин за числом операцій є вельми актуальним питанням, позитивне вирішення якого має як наукове, так і незаперечне практичне значення.

\section{Мета роботи}

Метою даної роботи було дослідження технологічного процесу оптимізації тонкого шліфування деталей обертання поліграфічної техніки (підшипники ковзання, втулки, ролики транспортних систем, підтримувачі і т. п.), що виготовлені з новітніх марок зносостійких композитів на основі регенерованих шліфувальних відходів високолегованих сталей 86ХНФТ, 5ХЗВЗМФС, 11РЗАМЗФ, 7ХГ2ВМФ та алюмінієвих сплавів АК8МЗг, АК12M2МгH, АM4,5Кд та розробка рекомендацій для виробництва, що забезпечують досягнення високих параметрів якості поверхонь оброблення у поєднанні з раціональними техніко-економічними показниками виробництва.

\section{Результати проведених досліджень}

Оптимальна кількість операцій шліфування деталей 3 новітніх композитних сплавів 3 отриманням мінімальних значень параметра шорсткості $\mathrm{R}_{\mathrm{a}}$ після оброблення може бути встановлена на основі аналізу трудомісткості обробки деталі при одній, двох чи більше операцій.

Кожний варіант - повинен забезпечити отримання деталі 3 заданою шорсткістю поверхні, точністю оброблення та якістю поверхневого шару.

За оптимальний варіант може бути прийнятий той, що (при умові виконання високих вимог якості) забезпечує мінімум трудомісткості шліфування за штучно-калькуляційному часу обробки

$$
\begin{aligned}
& \mathrm{T}_{\text {ш.к. }}=\mathrm{T}_{\mathrm{o}}+\mathrm{T}_{\text {в }}+ \\
& +\mathrm{T}_{\text {обсл. }}+\mathrm{T}_{\text {від. }}+\frac{\mathrm{T}_{\text {п-з }}}{\mathrm{n}},
\end{aligned}
$$




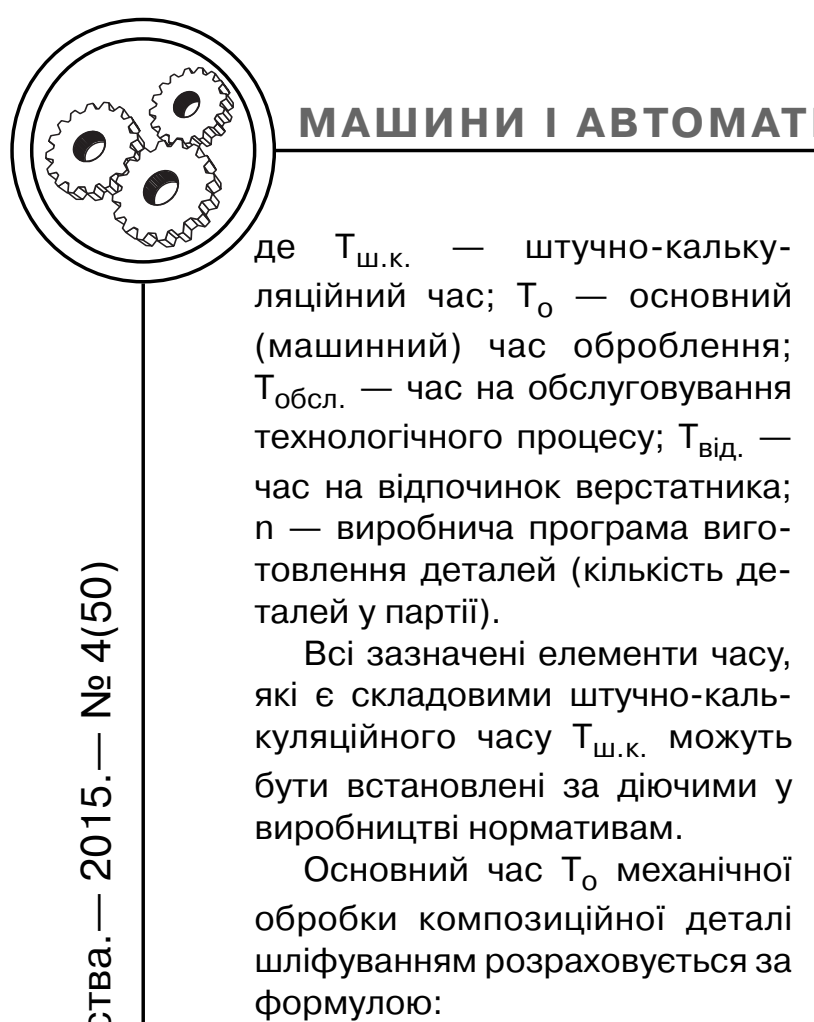

$$
\mathrm{T}_{\mathrm{o}}=\frac{\mathrm{F}}{\mathrm{Q}_{\mathrm{n}}},
$$

де $\mathrm{F}$ - площа поверхні оброблення у $\mathrm{Mm}^{2} ; \mathrm{Q}_{\mathrm{n}}$ - продуктивність шліфування по площі обробки в мм $^{2} /$ хв.;

$$
Q_{n}=\frac{Q_{M}}{\Pi},
$$

де $\mathrm{Q}_{\mathrm{M}}$ - продуктивність шліфування за об'ємом композиту, що зрізуеться абразивними зернами в мм $3 /$ хв.; П - радіальний припуск під шліфування в мм.

Продуктивність шліфування $Q_{M}$ залежить від об'єму металу, що зрізується з поверхні деталі кожним абразивним зерном та кількості поодиноких зрізів.

Найбільш типовими зрізами при тонкому чистовому шліфуванні є зрізи, які схожі на сегменти. У цьому випадку (згідно прийнятих на рис. 1 координат) елементарний об'єм однієї чверті риски визначається згідно рівняння:

$$
\mathrm{dV}_{\mathrm{p}}=\varphi(\mathrm{y}, \mathrm{z}) \mathrm{dydz},
$$

а повний об'єм сегментоподібної риски за рівнянням:

$$
\mathrm{V}_{\mathrm{p}}=4 \int_{0}^{\mathrm{y}} \int_{0}^{\mathrm{z}} \varphi(\mathrm{y}, \mathrm{z}) \mathrm{dydz}
$$

де $\varphi(y, z)-$ рівняння поверхні, яка обмежує об'єм риски.

Число поодиноких зрізів $\mathrm{N}$ у хвилину може бути розраховане за формулою:

$$
\mathrm{N}=6 \cdot 10^{4} \mathrm{~B} v_{\mathrm{K}} \mathrm{n}_{3},
$$

де В - висота шліфувального кругу в мм; $v_{\text {к }}$ - швидкість обертання абразивного кругу в м/с; $\mathrm{n}_{3}$ - кількість зерен, що розміщені на 1 мм² площі поверхні кругу.

Абразивні зерна на поверхні круга розташовані на різних рівнях і тому врізаються в поверхню деталі, що шліфується, на різний рівень. Кількість зерен, що знаходяться між поверхнями круга по глибині у і y + dy у напрямку радіуса, буде дорівнювати:

$$
\mathrm{dn}_{3}=\mathrm{f}(\mathrm{y}) \mathrm{dy},
$$

де $\mathrm{f}(\mathrm{y})$ - функція розподілу вершин абразивних зерен по глибині різання.

Об'єм композитного матеріалу, що зрізується за хвилину зернами у шарі dy, враховуючи рівняння 5-7, визначається згідно формули:

$$
\begin{gathered}
d Q_{M}=24 \cdot 10^{4} B v_{k} . \\
\cdot \int_{0}^{y}\left[f(y) \int_{0}^{y} \int_{0}^{z} \varphi(y, z) d y d z\right] d y .
\end{gathered}
$$




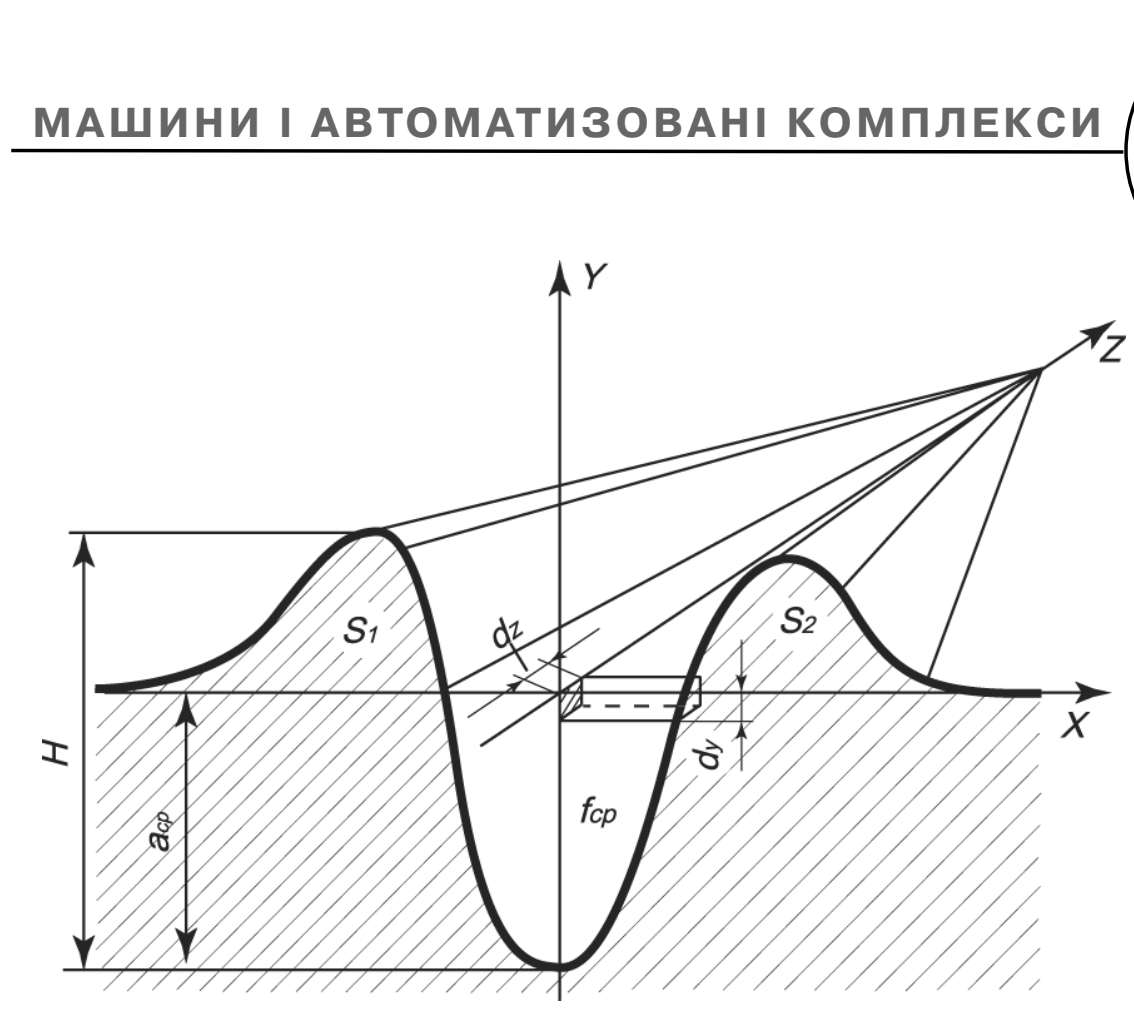

Рис. 1. Схема поодинокої риски при шліфуванні

Виконавши операцію інтегрування та підставляючи отримане значення $Q_{M}$ в рівняння (3), отримуємо загальне диференційне рівняння продуктивності процесу шліфування композитних деталей тертя друкарських машин (за умови, що встановлена функція розподілу абразивних зерен по глибині шару оброблення та отримано рівняння поверхні, що обмежує об'єм риски):

$Q_{n}=\frac{24 \cdot 10^{4} \mathrm{Bv}_{k} \int_{0}\left[f(y) \iint_{0} \varphi(y, z) d y d z d y\right.}{\Pi}$.

Якщо відома відстань $\mathrm{I}_{\phi}$ між абразивними зернами, які розташовані на поверхні шліфувального кругу, то кількість зрізів $\mathrm{N}$ оброблюваного матеріалу абразивними зернами за хвилину визначається за формулою:

$$
\mathrm{N}=\frac{6 \cdot 10^{4} \mathrm{Bv}_{\mathrm{k}}}{\mathrm{l}_{\Phi}^{2}}
$$

За даними робіт [10-13] приймаємо:

$$
\mathrm{I}_{\phi}=3,5 \cdot 10^{3} \mathrm{I}_{\mathrm{O}},
$$

де $\mathrm{I}_{\mathrm{o}}$ - середній та найбільш ймовірний розмір зерна у попереку перерізу в мкм.

Об'єм риски $V_{p}$ за даними досліджень [10-13] можливо розглядати як об'єм двох пірамід зі спільною базою. В цьому випадку:

$$
\mathrm{V}_{\mathrm{p}}=\frac{2 \cdot 10^{-3}}{3} \mathrm{f}_{\mathrm{cp}} \mathrm{L}
$$

де $\mathrm{f}_{\mathrm{cp}}$ - середня площа перерізу риски в мкм²; L - половина дуги контакту при сегментоподібному зрізі стружки, що дорівнює дузі контакту у вигляді коми, в мм. 


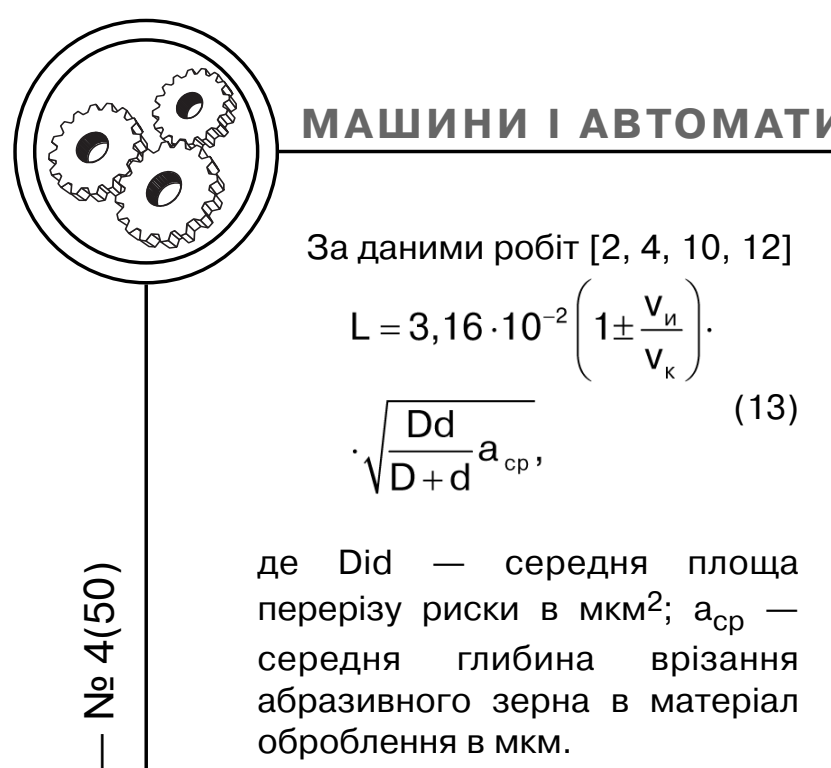

При $\mathrm{a}_{\mathrm{cp}} / \rho \leq 0,3$ значення $\mathrm{f}_{\mathrm{cp}}$ може бути розраховано згідно приблизній залежності:

$$
f_{c p}=1,8 a_{c p} \sqrt{\rho a_{c p}},
$$

де $\rho-$ радіус округлення абразивних зерен в мкм.

Об'єм риски $\mathrm{v}_{\mathrm{p}}$, яка утворюється при різанні, завжди більший за об'єм матеріалу, що зрізується кожним окремим зерном. 3 урахуванням загальноприйнятого коефіцієнта витискування К К [10-16] отримаємо:

$$
\frac{V_{M}}{V_{p}}=1-K_{B}=1-\frac{S_{1}+S_{2}}{f_{c p}}
$$

Витискування матеріалу кожним окремим зерном обумовлює також зростання шорсткості у ході процесу різання - дряпання (рис. 1). Введемо коефіцієнт перевищення шорсткості:

$$
\mathrm{K}_{\mathrm{R}}=\frac{\mathrm{a}_{\mathrm{cp}}}{\mathrm{H}}=\frac{\mathrm{a}_{\mathrm{cp}}}{\mathrm{R}_{\mathrm{z}}} .
$$

Зробивши необхідні підстановки у рівняння 3 , отримуємо залежність:
$Q_{n}=\frac{\left(1 \pm \frac{v_{u}}{60 v_{k}}\right) B \sqrt{\frac{D d}{D+d} K_{R} R_{z}} \quad(17)}{I_{0}^{2} \Pi}$,

де $\mathrm{K}_{\mathrm{Q}}$ - коефіцієнт, що враховує можливість підвищення продуктивності у початковий період шліфування за рахунок форсування режимів різання $[4,12$, 14-16].

Отримана залежність може бути розподілена на дві функціональні частини:

першу, яка залежить від розмірів шліфувального кругу і деталі:

$$
S=B \sqrt{\frac{D d}{D+d}}
$$

і другу, що залежить від розмірів зерна, режиму шліфування та припуску:

$$
G=\frac{\cdot\left(1 \pm \frac{v_{u}}{60 v_{K}}\right) \sqrt{K_{R} R_{z}}}{l_{0}^{2}} .
$$

Величина G може бути прийнята у якості продуктивності чистових процесів шліфування.

Коефіцієнти $\mathrm{K}_{\mathrm{B}}$ та $\mathrm{K}_{\mathrm{R}}$, при різанні-дряпанні, встановлені експериментально і для різних типів високозносостійких композитів (зокрема, при шліфуванні заготовок підшипників ковзання для поліграфічних машин) перебувають у межах $\mathrm{K}_{\mathrm{B}}=$ $0,2 \div 0,7 ; K_{R}=0,4 \div 0,8$ (табл.).

Для аналізу впливу числа чистових операцій на показник 
Коефіцієнти витискування $\mathrm{K}_{\mathrm{B}}$ та перевищення шорсткості $\mathrm{K}_{\mathrm{R}}$ для різних зносостійких композитівпри тонкому шліфуванні підшипників ковзання

\begin{tabular}{|l|c|c|}
\hline \multirow{2}{*}{ Тип композитного сплаву } & \multicolumn{2}{|c|}{ Значення коефіціентів } \\
\cline { 2 - 3 } & $\mathrm{K}_{\mathrm{B}}$ & $\mathrm{K}_{\mathrm{R}}$ \\
\hline На основі сталі 86ХНФТ & 0,70 & 0,80 \\
\hline На основі сталі 5ХЗВ3МФС & 0,65 & 0,75 \\
\hline На основі сталі 11Р3АМЗФ & 0,67 & 0,70 \\
\hline На основі сталі 7ХГ2ВМФ & 0,58 & 0,65 \\
\hline На основі алюмінію АК12М2МгН & 0,35 & 0,48 \\
\hline На основі алюмінію АК8МЗг & 0,28 & 0,45 \\
\hline На основі алюмінію АМ4,5Кд & 0,20 & 0,40 \\
\hline
\end{tabular}

продуктивності $G$ необхідно визначити значення $П \mathrm{i}_{\mathrm{o}}$ у вигляді функцій від параметра шорсткості поверхні $\mathrm{R}_{\mathrm{a}}$. Припуск на шліфування П визначається похибкою геометричної форми деталі, глибиною дефектного шару, що утворюється при обробленні поверхні, яка передувала тонкому шліфуванню.

Припуск, що встановлюється показниками попередньої шорсткості поверхні, може бути розрахований з рівняння:

$$
\Pi=10^{-3}\left(C_{0} \cdot R_{a_{1}}-C_{1} \cdot R_{a_{2}}\right),
$$

де $\mathrm{C}_{\mathrm{o}}$ i $\mathrm{C}_{1}-$ коефіцієнти нерівномірності шорсткості до та після шліфування; $\mathrm{R}_{\mathrm{a}_{1}}$ i $\mathrm{R}_{\mathrm{a}_{2}}-$ параметри шорсткості поверхні відповідно до та після шліфування.

Зменшення шорсткості поверхні можливо отримати тільки при умові шліфування абразивним кругом зазначеної конкретної зернистості ( $\mathrm{I}_{\mathrm{o}}=$ const) за рахунок суттєвого зменшення глибини занурення абразивних зерен у матеріал, що шліфується, (виходжування), а також при умові застосування кругів іншої зернистості з одночасною зміною параметрів шліфувального кругу та факторів режимів різання, включно зі зміною складу мастильноохолоджуючої рідини (МОР), яка використовується для інтенсифікації ходу процесу тонкого шліфування.

Тоді залежність $\mathrm{I}_{\mathrm{o}}$ від $\mathrm{R}_{\mathrm{a}_{1}}$ може бути надана у вигляді рівняння:

$$
\mathrm{I}_{0}=\mathrm{a}_{0} \cdot \mathrm{R}_{\mathrm{a}_{1}}^{\mathrm{a}_{\mathrm{p}}},
$$

де $a_{o}$ i $a_{p}-$ постійні регресії (встановлюються замірами при виробничих випробуваннях технологічного процесу).

При тонкому абразивному шліфуванні підшипників ковзання друкарських машин КВА «Rapida-105» та «STARBINDER1509» 3 високолегованого композиту 86Х6НФТ з домішками твердого мастила $\mathrm{C}_{\mathrm{a}} \mathrm{F}_{2}$ абразивними кругами 3 карбіду кремнію зеленого зернистістю 14 мкм на еластичній гліфталевій зв'язці Гл (63СМ14Гл) на прецизійному круглошліфувальному верстаті AS-250 «Werkzojt» (ФРН) [2-4] отримана залежність: 


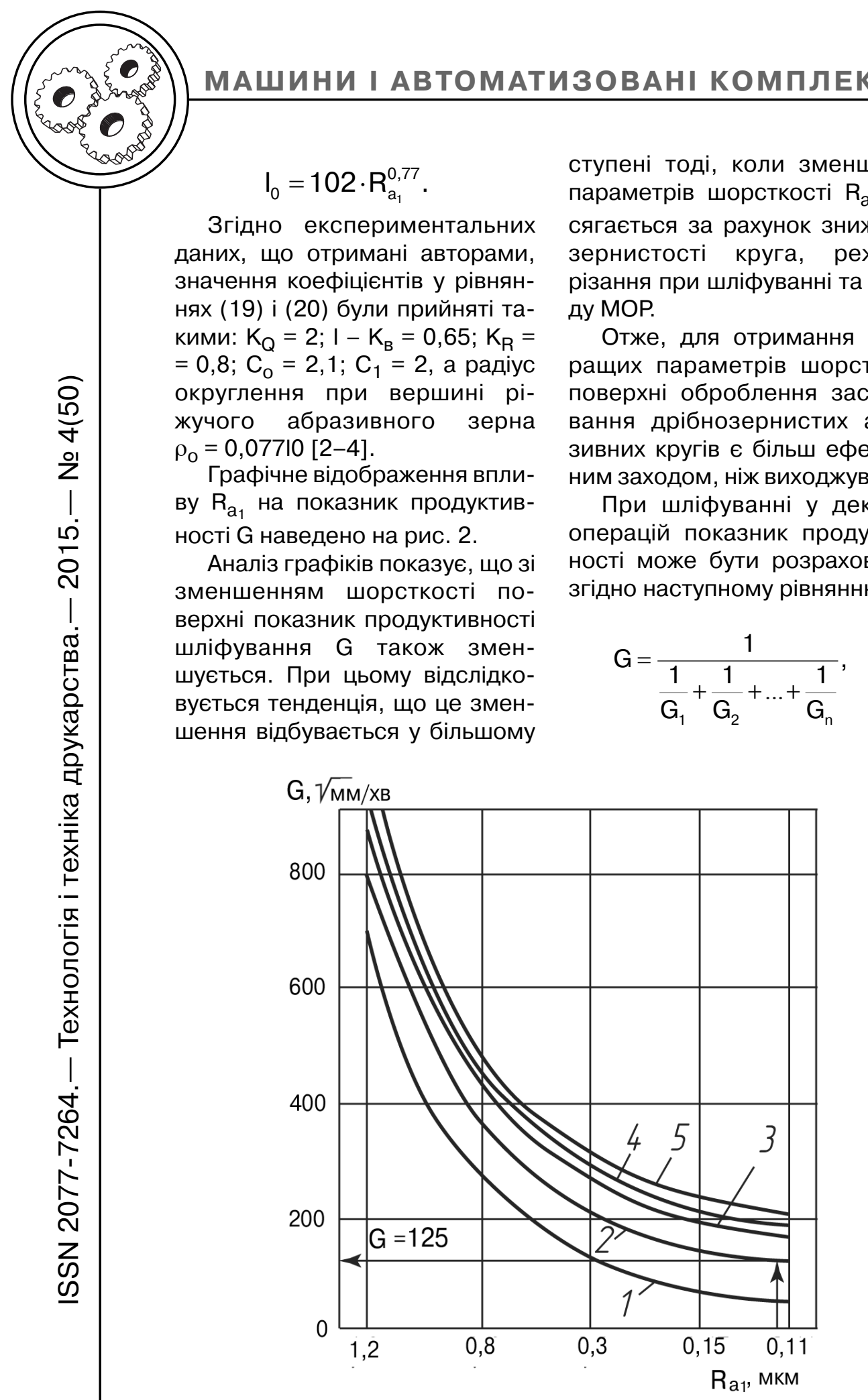

Рис. 2. Залежність показника продуктивності G від числа чистових операцій $\mathrm{n}$ та необхідної шорсткості поверхні $\left(\mathrm{R}_{\mathrm{a}_{0}}=2,4 \mathrm{M \kappa м} ; \mathrm{V}_{\mathrm{k}}=35 \mathrm{M} / \mathrm{c}\right)$ :

$$
1-n=1 ; 2-n=2 ; 3-n=3 ; 4-n=4 ; 5-n=10
$$


де $\mathrm{n}$ - число чистових операцій; $\mathrm{G}_{1}, \ldots, \mathrm{G}_{\mathrm{n}}$ - показники продуктивності кожної операції, які розраховують за формулою (19) зі значенням перемінних, які відповідають кожній операції.

Підставляючи значення $\mathrm{G}_{1}$, $\ldots, \mathrm{G}_{\mathrm{n}}$ при значеннях $\mathrm{f}_{\mathrm{cp}}$, П та $\mathrm{I}_{\mathrm{o}}$ із рівнянь (14), (20) та (21), отримуємо:

$G=\frac{750}{\frac{R_{a_{0}}-R_{a_{01}}}{R_{a_{01}}^{0,873}}+\frac{R_{a_{01}}-R_{a_{02}}}{R_{a_{02}}^{0,873}}+\frac{R_{a_{0 n-1}}-R_{a_{0 n}}}{R_{a_{0 n}}^{0,873}}}$,

де $\mathrm{R}_{\mathrm{a}_{01}}, \mathrm{R}_{\mathrm{a}_{02}}, \ldots, \mathrm{R}_{\mathrm{a}_{0 \mathrm{n}}}$ - параметри шорсткості поверхонь після першої, другої і подальших операцій.

Оптимальні значення шорсткості поверхні після проміжних операцій можуть бути встановлені при дослідженнях методом наближення з допомогою ПЕОМ чи графоаналітичним методом.

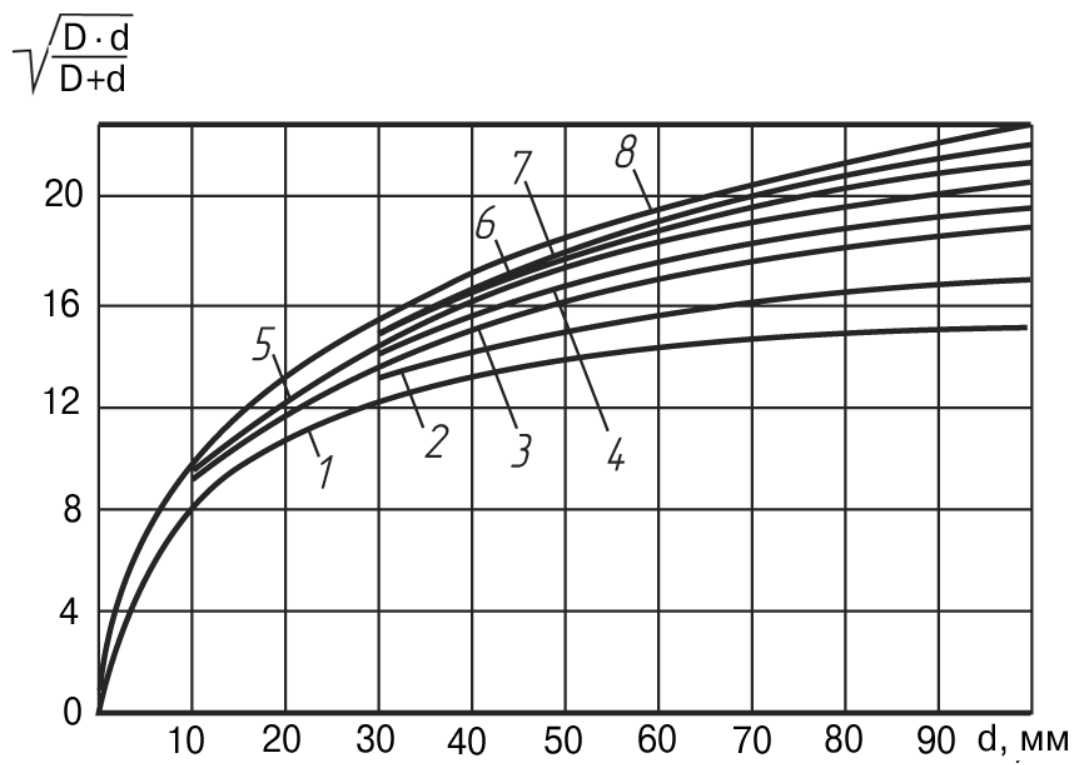

Рис. 3. Залежність значень $\sqrt{\frac{D \cdot d}{D+d}}$ від діаметру деталі $d$, що шліфується та діаметру кругу Д: 1 - Д = 30 мм; 2 - Д = 40 мм; 3 - Д = 50 мм; 4 - Д = 60

мм; 5 - Д = 70 мм; 6 - Д = 80 мм; 7 Д = 90 мм; $8-$ Д = 100 мм
Для графоаналітичного рішення задачі на рис. 2 графічно наведена залежність показника продуктивності G від числа операцій шліфування та заданої шорсткості поверхні оброблення, а на рис. 3 - залежність $\sqrt{\frac{D \cdot d}{D+d}}$ від діаметру d деталі, що шліфується та діаметру шліфувального кругу Д.

На рис. 4 зображена номограма для встановлення продуктивності процесу шліфування $Q_{n}$.

Розрахунки оптимальної кількості числа шліфувальних операцій відбувається наступним чином:

1) за рис. 2 з врахуванням попередньої і необхідної шорсткості поверхні визначається показник продуктивності G для різних варіантів технологічних процесів (при одній, двох і більше чистових операціях); 


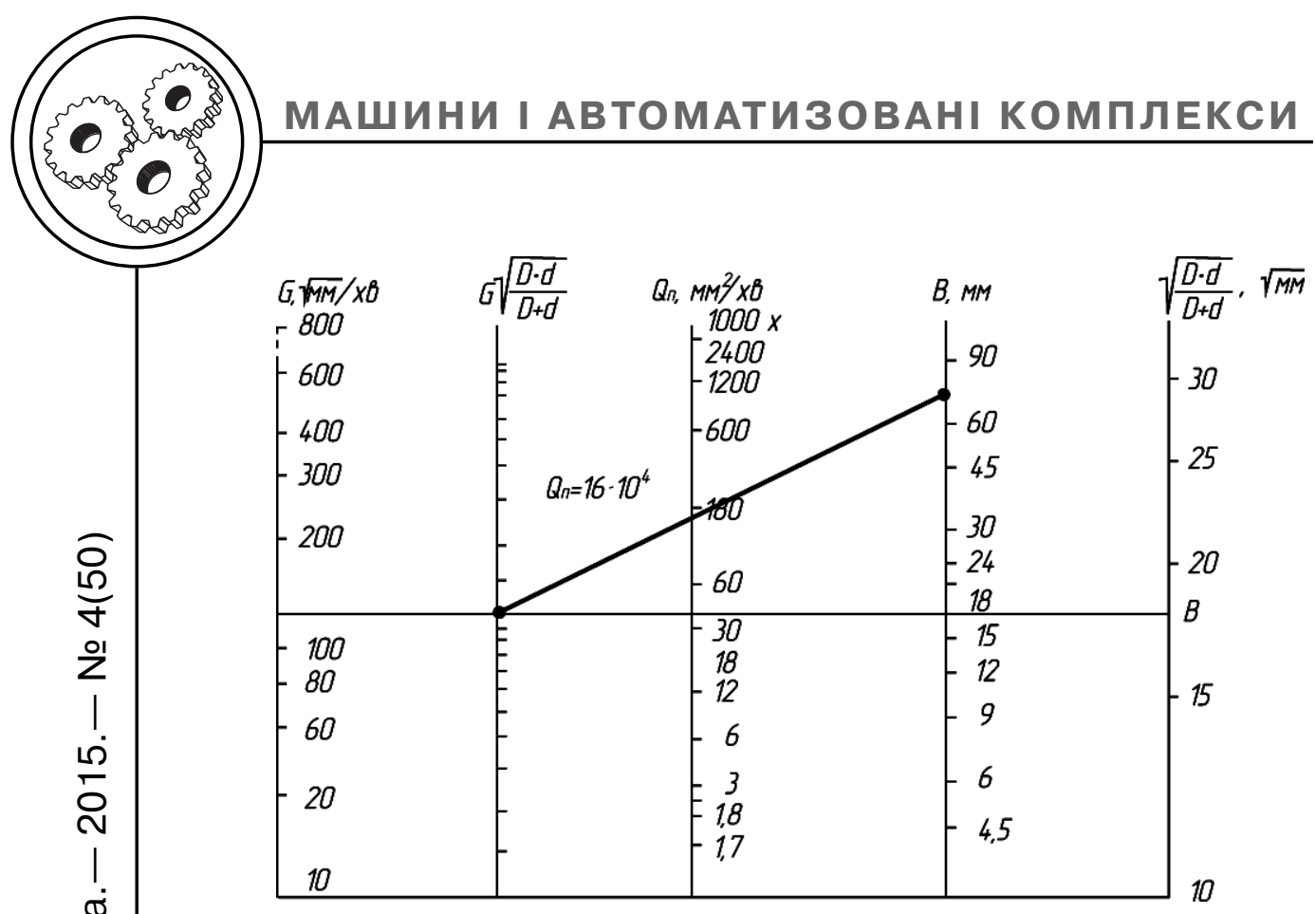

Рис. 4. Номограма для встановлення продуктивності процесу тонкого шліфування деталей тертя поліграфічних машин, які виготовлені з композитів 86ХНФТ та 11РЗАМЗФ

2) за рис. 3 по розмірам діаметрів деталі, що повинна бути оброблена та шліфувального круга визначається зна-

чення $\sqrt{\frac{D \cdot d}{D+d}}$;

3) за рис. 4 по знайденим значенням $G, \sqrt{\frac{D \cdot d}{D+d}}$ та по висоті

кругу В встановлюють продуктивність процесу шліфування $\mathrm{Q}_{\mathrm{n}}$ для кожного з варіантів;

4) за формулою (1) штучнокалькуляційного часу $\mathrm{T}_{\text {ш.к }}$ розраховується трудомісткість обробки деталі для всіх варіантів та здійснюється вибір варіанту, який забезпечує мінімальну трудомісткість.

Згідно викладеної методики виконані розрахунки зі встановлення оптимального числа операцій шліфування заготовок підшипників ковзання друкарсь- ких машин (dil - діаметр та довжина підшипника зі зносостійкого композиту 86ХНФТ) різних розмірів для отримання параметра шорсткості поверхні $R_{a}$ у межах 0,09-0,12 мкм). Зазначимо, що значення параметру шорсткості поверхні $\mathrm{R}_{\mathrm{a}}$ після попереднього чорнового шліфування знаходилось у межах 2,2-2,4 мкм.

Результати розрахунків наведені на рис. 5. Всі підшипники, розміри яких відповідають точкам А, В, С, що розташовані нижче кривої лінії, доцільно (з прийнятною ефективністю) обробляти в одну операцію, вище (точки Д та Е) - в дві операції.

Експериментальна перевірка запропонованої методики була виконана при оцінці точності моделювання процесу шліфування по рівнянню (17). у дослідах, які виконувались в лабораторно-виробничих умовах, 
d, $M M$

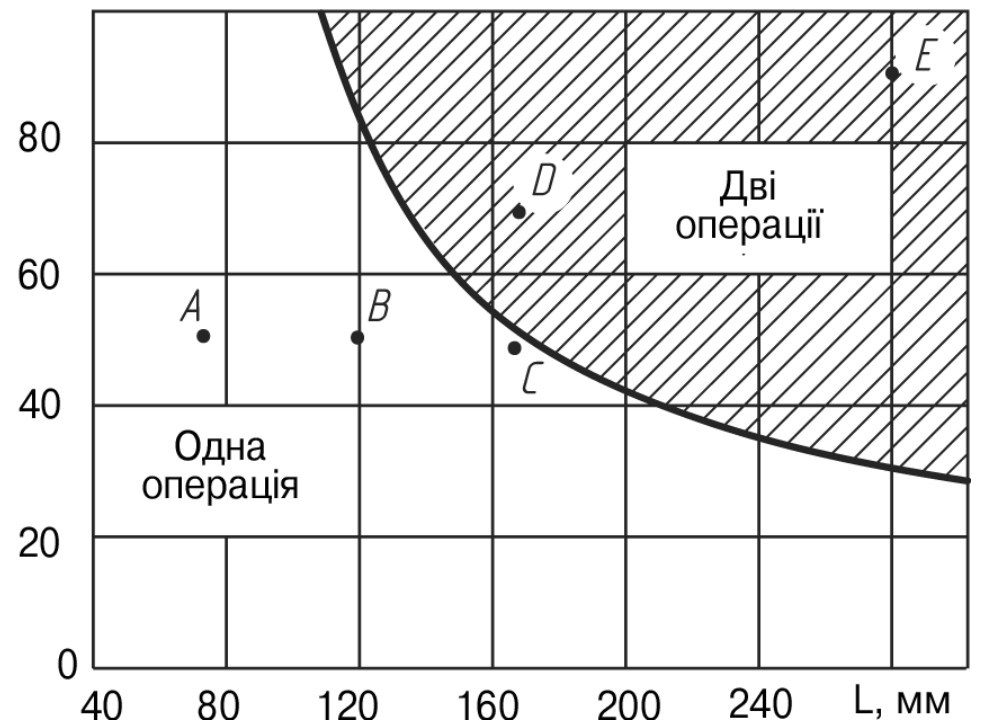

Рис. 5. Визначення оптимального числа чистових операцій шліфування композитних підшипників ковзання друкарських машин для отримання відповідних показників параметра шорсткості поверхні $\mathrm{R}_{\mathrm{a}}$

співставлялись значення розрахованої та фактичної продуктивності $Q_{M}=Q_{n} \cdot П$ при тонкому абразивному шліфуванні кругами різних характеристик.

Отримані результати показали, що відхилення теоретично розрахованих значень продуктивності від експериментальних не перевищують 7-15 \%.

Це дозволяє стверджувати про задовільний рівень оцінки моделювання процесу шліфування композитних деталей тертя з допомогою рівняння (17) та об'єктивну можливість промислового впровадження розробленої методики у промислову практику для високоякісної обробки деталей поліграфічних машин, що виготовлені 3 новітніх марок високозносостійких композитних матеріалів.

\section{Висновки}

Узагальнюючи комплекс виконаних досліджень, необхідно зробити важливі як наукові, так і практичні висновки.

1. Вперше досліджено питання абразивного оброблення нових композиційних сплавів, синтезованих на основі утилізованих та регенерованих шліфувальних відходів інструментальних сталей та алюмінію, з забезпеченням високого рівня продуктивності механічної обробки у поєднанні з досягненням найвищих параметрів якості оброблення поверхонь композитних деталей тертя.

2. Показано, що основні закономірності забезпечення продуктивності обробки на шліфувальних операціях співпадають із засадничими положеннями економічної теорії розвитку 


\section{МАШИНИ І АВТОМАТИЗОВАНІ КОМПЛЕКСИ}

сучасного виробництва та базовими закономірностями тонкого шліфування при абразивній обробці важкооброблюваних та високозносостійких композитних матеріалів.

3. Розроблена, експериментально перевірена та впроваджена у виробництво методика оптимізації процесу тонкого шліфування композитних деталей тертя поліграфічних машин по числу операцій, що дозволяє забезпечити отримання високої якості поверхонь оброблення та досягти нормованого рівня продуктивності обробки абразивним шліфуванням.

4. Подальші дослідження доцільно виконувати у царині застосування для тонкого високоякісного шліфування новітніх типів композитних матеріалів найсучасніших високоефективних шліфувальних інструментів на основі синтетичних алмазів (AC) та кубічного нітриду бора кубаніту (КНБ, Україна), ельбору (ЛО, Росія) та боразону (ВО, США).

\section{Список використаної літератури}

1. Роїк Т. А. Композиційні підшипникові матеріали для підвищених умов експлуатації : монографія / Т. А. Роїк, П. О. Киричок, А. П. Гавриш. - К. : НТУУ «КПІ», 2007. - 404 c.

2. Технологія поліграфічного машинобудування : навч. посіб. / [П. О. Киричок, Т. А. Роїк, А. В. Шевчук та ін.]. - К. : НТУУ «КПІ», 2014. - 504 с.

3. Новітні композиційні матеріали деталей тертя поліграфічних машин : монографія / [Т. А. Роїк, А. П. Гавриш, П. О. Киричок, Ю. Ю. Віцюк]. - К. : НТУУ «КПІ», 2014. - 427 с.

4. Фінішне оброблення зносостійких деталей друкарських машин : навч. посіб. / [П. О. Киричок, Т. А. Роїк, А. П. Гавриш та ін.]. - К. : НТУУ «КПІ», 2014. $-404 \mathrm{c}$.

5. Новітні технології виробництва стандартизованих виробів : монографія / [О. А. Гавриш, Ю. Ю. Віцюк, Т. А. Роїк, А. П. Гавриш]. - К. : НТуУ «КП।», 2012. - $204 \mathrm{c.}$

6. Костецкий Б. И. Трение, смазка и знос в машинах / Б. И. Костецкий. - К. : Техника, 1970. - 396 с.

7. Костецкий Б. И. Сопротивление изнашиванию деталей машин / Б. И. Костецкий. - М. : Машгиз, 1959. - 216 с.

8. Крагельский И. В. Основы расчетов на трение и знос / И. В. Крагельский. - М. : Машиностроение, 1977. - 526 с.

9. Рыжов Э. В. Технологические методы повышения износостойкости деталей машин / Э. В. Рыжов. - К. : Наукова думка, 1984. - 340 с.

10. Маслов Е. Н. Теория шлифования материалов / Е. Н. Маслов. - М. : Машиностроение, 1974. - 320 с.

11. Рыжов Э. В. Высокоефективные процессы финишной обработки / Э. В. Рыжов. - К. : Наукова думка, 1984. - 340 с.

12. Байкалов А. К. Введение в теорию шлифования / А. К. Байкалов. К. : Наукова думка, 1978. - 207 с.

13. Захаренко Н. П. Алмазные инструменты и процессы обработки / Н. П. Захаренко. - К. : Техника, 1980. - 216 с.

14. Лавриненко В. І. Надтверді абразивні матеріали в механообробці : Енциклопедичний довідник під заг. ред. акад. НАН України М. В. Новікова. - К. : ІНМ НАН України, 2013. - 456 с. 
15. Основи теорії різання матеріалів : підручник / [Мазур М. П., Внуков Ю. М., Доброскок В. Л. та ін.] ; під заг. ред. М. П. Мазура. - Львів. : Новий світ, 2010. - 423 с.

16. Инструменты из сверхтвердых материалов / под ред. акад. НАН Украины Н. В. Новикова, д.т.н. С. А. Клименко. - М. : Машиностроение, 2014. -607 c.

\section{References}

1. Roik T. A. Kompozytsiini pidshypnykovi materialy dlia pidvyshchenykh umov ekspluatatsii : monohrafiia / T. A. Roik, P. O. Kyrychok, A. P. Havrysh. - K. : NTUU «KPI», 2007. - $404 \mathrm{~s}$.

2. Tekhnolohiia polihrafichnoho mashynobuduvannia : navch. posib. / [P. O. Kyrychok, T. A. Roik, A. V. Shevchuk ta in.]. - K. : NTUU «KPI», 2014. $504 \mathrm{~s}$.

3. Novitni kompozytsiini materialy detalei tertia polihrafichnykh mashyn : monohrafiia / [T. A. Roik, A. P. Havrysh, P. O. Kyrychok, lu. lu. Vitsiuk]. - K. : NTUU «KPI», 2014. - $427 \mathrm{~s}$.

4. Finishne obroblennia znosostiikykh detalei drukarskykh mashyn : navch. posib. / [P. O. Kyrychok, T. A. Roik, A. P. Havrysh ta in.]. - K. : NTUU «KPI», 2014. -404 s.

5. Novitni tekhnolohii vyrobnytstva standartyzovanykh vyrobiv : monohrafiia / [O. A. Havrysh, lu. lu. Vitsiuk, T. A. Roik, A. P. Havrysh]. — K. : NTUU «KPI», 2012. $-204 \mathrm{~s}$.

6. Kosteckij B. I. Trenie, smazka i znos v mashinah / B. I. Kosteckij. - K. : Tehnika, 1970. - $396 \mathrm{~s}$.

7. Kosteckij B. I. Soprotivlenie iznashivaniju detalej mashin / B. I. Kosteckij. - M. : Mashgiz, 1959. - $216 \mathrm{~s}$.

8. Kragel'skij I. V. Osnovy raschetov na trenie i znos / I. V. Kragel'skij. - M. : Mashinostroenie, 1977. - $526 \mathrm{~s}$.

9. Ryzhov Je. V. Tehnologicheskie metody povyshenija iznosostojkosti detalej mashin / Je. V. Ryzhov. - K. : Naukova dumka, 1984. - 340 s.

10. Maslov E. N. Teorija shlifovanija materialov / E. N. Maslov. - M. : Mashinostroenie, 1974. $-320 \mathrm{~s}$.

11. Ryzhov Je. V. Vysokoefektivnye processy finishnoj obrabotki / Je. V. Ryzhov. - K. : Naukova dumka, 1984. - $340 \mathrm{~s}$.

12. Bajkalov A. K. Vvedenie v teoriju shlifovanija / A. K. Bajkalov. - K. : Naukova dumka, 1978. - $207 \mathrm{~s}$.

13. Zaharenko N. P. Almaznye instrumenty i processy obrabotki / N. P. Zaharenko. - K. : Tehnika, 1980. - $216 \mathrm{~s}$.

14. Lavrynenko V. I. Nadtverdi abrazyvni materialy $v$ mekhanoobrobtsi : Entsyklopedychnyi dovidnyk pid zah. red. akad. NAN Ukrainy M. V. Novikova. K. : INM NAN Ukrainy, 2013. - 456 s.

15. Osnovy teorii rizannia materialiv : pidruchnyk / [Mazur M. P., Vnukov lu. M., Dobroskok V. L. ta in.] ; pid zah. red. M. P. Mazura. - Lviv. : Novyi svit, 2010. $-423 \mathrm{~s}$.

16. Instrumenty iz sverhtverdyh materialov / pod red. akad. NAN Ukrainy N. V. Novikova, d.t.n. S. A. Klimenko. - M. : Mashinostroenie, 2014. - 607 s.

В статье приведены результаты теоретико-экспериментальных исследований по оптимизации по числу операций технологического процесса тонкого абразивного шлифования вы- 
сокоизносостойких композитных деталей трения полиграфических машин, изготовленных из новых типов композиционных материалов, синтезированных на основе отходов высоколегированных штампованных и инструментальных сталей, а также алюминиевых сплавов. Разработана новая методика оценки производительности шлифования с учетом требований высокого качества поверхностей деталей и факторов экономики производства. Установлены аналитические зависимости, которые объединяют требования к абразивным инструментам, режимам резания, параметрам шероховатости поверхностей деталей и вопросы экономики процесса производства, в первую очередь, высокой производительности процесса шлифования. Разработаны рекомендации для производства.

\section{Ключевые слова: композитные материалы; абразивное шлифование; шероховатость поверхности; производительность процесса шлифования.}

In the article there were presented the theoretical and experimental research results of optimization by operations number of the technological process for fine abrasive grinding of high were-resistant composite friction parts for printing machines, which were manufactured from new type of composite materials and which were synthesized based on high alloyed stamp and tool steels wastes and aluminum alloys too. It was created the new method for estimation of the grinding productivity with taking into account the requirements of high quality of the part's surfaces and economic factors of production. The analytical dependences which combine the requirements for abrasive tool, cutting parameters, roughness parameters of parts' surfaces and the economical questions of production process, first of all, high productivity of the abrasive grinding, have been determined. It was developed the recommendations for industrial purpose.

Keywords: composite materials; abrasive grinding; roughness surface; productivity of the grinding process. 